\title{
Toward an applied methodology for price comparison studies of farmers' markets and competing retailers at the local scale
}

\author{
Joshua Long, ${ }^{a}$ M. Anwar Sounny-Slitine, ${ }^{\mathrm{b}}$ Katherine Castles, ${ }^{\mathrm{c}}$ Jillian Curran, ${ }^{\mathrm{c}}$ Harrison Glaser, ${ }^{\mathrm{c}}$ \\ Ellen Hoyer, ${ }^{\mathrm{c}}$ Whitney Moore, ${ }^{\mathrm{c}}$ Lisa Morse, ${ }^{\mathrm{c}}$ Molly O'Hara, ${ }^{\mathrm{c}}$ and Ben Parafina ${ }^{\mathrm{c}}$ \\ Southwestern University
}

Submitted October 5, 2012 / Revised January 9, April 1, and April 23, 2013 / Accepted May 5, 2013 /

Published online June 21, 2013

Citation: Long, J., Sounny-Slitine, M. A., Castles, K., Curran, J., Glaser, H., Hoyer, E., Moore, W., Morse, L., O'Hara, M., \& Parafina, B. (2013). Toward an applied methodology for price comparison studies of farmers' markets and competing retailers at the local scale. Journal of Agriculture, Food Systems, and Community Development, 3(3), 95-119. http://dx.doi.org/10.5304/jafscd.2013.033.010

Copyright (C) 2013 by New Leaf Associates, Inc.

\begin{abstract}
Qualitative research on food pricing in regional markets is currently underrepresented in the scholarly literature. The methods used in existing peer-reviewed studies tend to obscure important qualitative differences in the food items they compare and the retail spaces they source. Recently, some non-peer reviewed price comparison studies have emerged that point to some of the complications of earlier studies and offer alternative methods for data collection and comparison. Building upon the contributions of these latter works, this study attempts to improve upon previous studies and provide a set of methods that

a * Corresponding author: Joshua Long, Assistant Professor of Environmental Studies, Southwestern University, 1001 East University Drive, Georgetown, Texas 78626 USA; +1-512-863-1493; jlong@southwestern.edu

b M. Anwar Sounny-Slitine, Program Coordinator, Southwestern University Environmental Studies Program.

${ }^{c}$ Members of the 2012 Senior Environmental Studies Capstone course.
\end{abstract}

contribute thoughtfully to future studies. The main goal of this study is to advance research that would better inform consumers and the producers who serve them. The key contribution of this study is a new model for future price comparison studies that accurately provides accessible and practical information for farmers' market producers and consumers.

\section{Keywords}

consumer attitudes, farmers' markets, local food, price comparison studies, price premiums

\section{Introduction}

An increasing number of American consumers are becoming concerned with such agricultural issues as food origin, worker rights, ethical treatment of animals, growing practices, and other issues within the contemporary food system. Yet while there is no shortage of information available to consumers about how, why, and where they should purchase their food, studies that compare the prices of qualitatively similar food items within a local 
market area are largely absent from the peerreviewed scholarly literature. Accessible information from such a study may improve decisionmaking capacity for consumers who are currently presented with a complex diversity of food choices. Likewise, information from a localized pricecomparison study would better inform the business models of small-scale, direct-market producers and help them engage their customer base more effectively. The purpose of this research is to develop a set of reproducible methods for local price-comparison studies that (1) reflects the motivations and considerations of the contemporary local food shopper, and (2) presents relevant and accessible data that can benefit farmers' market consumers and producers.

As research for this paper revealed, however, conducting such a price-comparison study and presenting its findings in an accessible format can be a challenging task. Price-comparison studies (PCS) vary according to location and are also susceptible to methodological mistakes and bias. Further, the diversity and complexity of the modern food retail landscape makes one-dimensional, item-to-item comparisons difficult and even misleading. This paper addresses the empirical and theoretical issues that must be considered in order to develop a new PCS model. We begin with a review of the scholarly literature in order to evaluate the applicability of previous PCS, assess the consumer motivations of local food patrons, and gather relevant information regarding food price premiums. Next, information is presented about the specific study sites and the methods used to select items, record data, and compare prices. Following a presentation of findings, this paper offers a set of recommendations for future studies in an attempt to advance this mode of research. Ultimately, this study presents a new set of reproducible methods for conducting PCSs that can be presented in a clear and accessible manner to farmers' market producers and consumers.

\section{Case Study Background and Literature Review}

The impetus for this study emerged from a larger research project that included a survey of three farmers' markets in the Austin, Texas MSA (metropolitan statistical area). During research, market organizers and vendors mentioned the unreliability and inapplicability of existing PCSs. They suggested that a more robust set of methods for PCSs should be developed in order to provide vendors and consumers with accurate pricing information. In order to do this, we first reviewed existing PCSs in order to identify the strengths and weaknesses of those studies. We then engaged in a review of the literature on the local food movement and farm direct markets in order to better contextualize our study and inform our methods. This section summarizes that literature.

\section{Previous Price Comparison Studies}

Research that compares food pricing among farmers' markets and local competitors is currently underrepresented in the peer-reviewed literature. As of the writing of this manuscript, only two peerreviewed PCSs of farmers' markets and conventional grocery stores have appeared since 1980 (Gunderson \& Earl 2010; McGuirt, Jilcott, Liu, \& Ammerman, 2011). These studies are broad in scope and are not always useful for farmers' market vendors or consumers because they (1) do not reflect the complexity of the contemporary food retail landscape, (2) are not accessible to most consumers, and (3) do not reflect the changing preferences of the contemporary consumer.

The first known peer-reviewed PCS appeared over three decades ago (Sommer, Wing, \& Aitkens, 1980). Like studies that appeared much later, this research was broad in scope, considering the prices of over 350 items at 18 different certified Northern California farmers' markets and an undisclosed number of nearby supermarkets. The study revealed a price savings in favor of farmers' market at the time, determining that the "average unit cost in the supermarkets... was [US]70 and in the farmers' market it was [US]46 "' (Sommer et al., 1980, p. 47). Perhaps most notably, this study recognized the importance of conducting future research that considered such factors as quality, consumer motivation, and seasonality.

Three decades passed before PCSs appeared again in the scholarly literature. McGuirt et al. (2011) conducted an analysis of 12 farmers' markets and an undisclosed number of conventional 
supermarkets across North Carolina. The study recorded 230 food items for comparison. They also found "an overall price savings to consumers who shop at farmers' markets compared to supermarkets" (McGuirt et al., 2011, p. 91) across a diverse geographic landscape within the state. The McGuirt et al. research identifies the same methodological limitations and complications of conducting a PCS, including convenience, location, and price fluctuation. Another peer-reviewed study (Gunderson \& Earl, 2010) proposed a model of price-comparison research between supermarkets and farmers' markets in Florida for the stated purpose of "advis[ing] farmers how to more competitively price their produce" (p. 54). Their research provides detailed methods for a large-scale statistical pricing model to be carried out in 2010, but as of the writing of this manuscript, the results have not been published.

Alternatively, two non-peer reviewed studies (Claro, 2011; Pirog \& McCann, 2009) highlight some of the methodological challenges of conducting PCSs within regional food systems, calling attention to differences in food origin, quality, and seasonality when drawing comparisons and determining prices. ${ }^{1}$ Pirog and McCann (2009) recorded prices with the intent of comparing cost between "local" and "nonlocal" foods at Iowa markets. Unlike previous studies that had only compared two types of retail markets (farmers' markets and conventional supermarkets), this study considered four "natural grocery stores" and three butcher shops, as well as four conventional supermarket chains and six farmers' markets. Perhaps most importantly, the researchers considered food origin, certification, and growing or raising practices when comparing "like items" (pp. 3-5). A second study by Claro (2011) compared 12 "core items" at nine farmers markets and 10 grocery stores. Like the Pirog and McCann study, distinctions were made

${ }^{1}$ An additional price comparison analysis should be mentioned here. For at least three consecutive years, students at Seattle University's Albers School of Business have conducted informal price comparisons between local grocers and farmers' markets in the Seattle area. However, the details of this study — particularly the methodological considerations - have not been published, and we were unable to locate these details. between certified organic and nonorganic items, but unlike that research, little mention was made of food origin. The stated goals of the study included establishing "an overview of prices at farmers markets that consumers can expect to encounter"; offering information that could improve the effectiveness of SNAP (Supplemental Nutrition Assistance Program) beneficiaries; and providing "robust pricing data" that could inform vendors and farmers at markets (Claro, 2011, p. 4). The study succeeded in its aims, contributing detailed data for farmers and consumers in Vermont and successfully offering marketing suggestions to their intended audience. The Claro (2011) study, however, did not build upon many of the suggestions of the earlier studies, and its findings were limited to a regional audience.

This study draws from many of the methodological improvements and suggestions of Pirog and McCann (2009) and Claro (2011). In order to better inform this study, we reviewed the recent scholarly literature on direct food markets, their patrons, and their role in contemporary food culture. This review strongly influenced our choice of methods and our discussion of results.

\section{Farm Direct Markets and their Patrons}

The number of farmers' markets more than doubled in the first decade of the $21^{\text {st }}$ century (United States Department of Agriculture [USDA], 2012) and the number of community supported agriculture (CSA) programs reached 3,600 by the end of that decade (see Galt, 2011, for an alternative count). This trend has garnered significant attention from popular books, film, and mainstream media (Lavin, 2009; Long, 2011), and scholarly publications have paralleled this trend. As these studies reveal, consumers rarely make food choices based upon price alone.

First, community building and social interaction are important motivations for many farmers' market patrons (Farmer, Chancellor, Gooding, Shubowitz, \& Bryant, 2011; Feagan \& Morris, 2009; Hunt, 2007; Svenfelt \& Carlsson-Kanyama, 2010; Tiemann, 2008). Building upon Hinrichs' (2000; 2003) discussion of social embeddedness in local agriculture, Feagan and Morris (2009) argue that several forms of "embeddedness" drive consumer 
motivations and regularly supplant price as the primary factor in food selection. Social embeddedness implies a sense of connection, community, loyalty, and belonging to the material purchase of food items (Feagan \& Morris, 2009; Hunt, 2007). The purchase of items that exhibit those qualities therefore encourages a sense of identity and cohesion among consumers. In addition, farmers' markets represent an idealized landscape for support of the "local economy" both in terms of regional economic sustainability and perpetuation of social ties that are often seen as a necessary feature of sustainable communities (Lyson, Gillespie, \& Hilchey, 1995; Kingsolver, Hopp, \& Kingsolver, 2007; McKibben, 2007; Winter, 2003). Lastly, the space of the farmers' market is seen as a safe area of recreation, entertainment, and socialization, further adding to its role as a space for community building and social interaction (Farmer et al., 2011; Svenfelt \& Carlsson-Kanyama, 2010; Tiemann, 2008).

Second, there are political motivations for patronizing a farmers' market. Choosing to shop at a farmers' market is seen as a local act, but it is also sometimes portrayed as a politically motivated decision with global consequences (DeLind, 2011; Lavin, 2009). Popular books such as Schlosser (2001), Nestle (2002), Pollan (2006; 2009), Bendrick (2008), and films such as King Corn (2007), Fresh (2008), and Food Inc. (2008) criticize corporate retailers and industrial agribusiness while simultaneously romanticizing local, small-scale farmers and direct food markets. As scholarly authors point to the social and environmental consequences of corporate agribusiness (see for instance, Barrientos \& Dolan, 2007; Boucher, 1999; Patel, 2008; Shiva, 2000), popular writers provide step-by-step instructions for resisting global injustices through acts of local consumption - acts that are portrayed as more transparent, ethical, and environmentally friendly (Kingsolver et al., 2007; Pollan, 2008).

Lastly, empirical studies find that for many local food consumers, freshness, variety, value, and nutrition are also key motivating factors (Feagan \& Morris, 2009; McEntee, 2010; Onianwa, Mojica, \& Wheelock, 2006; Svenfelt \& Carlsson-Kanyama, 2010; Wolf, Spittler, \& Ahern, 2005; Zepeda, 2009; Zepeda \& Li, 2006). And while the consumer quest for fresh and healthy ingredients tends to be practiced disproportionately by different demographic groups, evidence suggests that an increasing number of Americans are making their way to the space of the farmers' market (Detre, Mark, \& Clark, 2010; Wolf et al., 2005; Zepeda, 2009).

\section{Paying the Price}

Numerous studies address the idea of a "local food price premium," with farmers' markets as one of the chief beneficiaries of that premium (Adams \& Adams, 2011; Adams \& Salois, 2010; Burnett, Kuethe, \& Price, 2011; Carpio \& Isengildina-Massa, 2009; Lyon, Collie, Kvarnbrink, \& Colquhoun, 2009; Toler, Briggeman, Lusk, \& Adams, 2009). Some time near the turn of the century, consumer preference for "local" began increasing significantly (Adams \& Salois, 2010), and as demand for local products increased, so did the local price premium. Carpio and Isengildina-Massa (2009) found that South Carolina consumers were willing to pay an average of $27 \%$ more for local produce and $23 \%$ more for local animal products. Adams and Adams (2011) found that while consumers across demographic groups exhibited a different level of willingness to pay the local premium, the overall average price was $76 \%$ higher for local foods. In short, there is strong evidence that consumers are increasingly willing to pay more for local foods, but there are additional factors that weigh on the consumer mind.

In addition to the local premium, Moser et al. (2011) and Burnett et al. (2011) both address several other "credence attributes" that affect a consumer's willingness to pay a higher price. These may be positive or negative in the mind of the consumer, and include production methods such as integrated pest management, genetic modification, the use of chemicals, and a host of other environmental and social concerns. The increased availability of these foods in retail markets denotes a shift in consumer preference for local and sustainable foods.

This shift has not gone unnoticed by corporate retailers who have strategically co-opted messages of "local" and "sustainable." Long (2011) discusses the inclusion of "surrogate" and "counternarratives" of sustainability in the supermarket landscape 
intended to mimic the authentic, local, and personal food experiences of farm direct markets. Drawing from the information produced by popular and alternative media, supermarkets follow with their own on-site narratives of local, personal, and "close-to-home" connections (Long, 2011). This has produced a complex retail landscape for the consumer in which they must critically evaluate competing messages of production practices, environmental impact, and social relationships. Incidentally, this has also produced a challenging environment for conducting a PCS. As this literature review argues, strictly quantitative price comparisons fall short of addressing the values of today's local food consumer.

\section{Study Site Information}

This study offers a new model for PCSs among farmers' markets and local retail competitors, but results may vary according to geographic location and retail competition. To account for this, the following section provides information about the geographic region studied, descriptions of the farmers' markets, and information about the nearest natural and conventional retailer grocers. All research was conducted in or near the Austin, Texas MSA during March and April 2012 by a nine-member research team, including the principle investigator and co-authors of this manuscript. Austin is a city of nearly 800,000 residents with more than 1.7 million in the extended MSA (U.S. Census Bureau, n.d.). Austin is considered one of the fastest growing U.S. metropolitan areas in terms of employment, population increase, and economic growth (Fisher, 2012; Florida, 2012). Austin's direct food markets grew steadily during the first decade of the $21^{\text {st }}$ century, and the MSA is now home to six active markets and nearly 20 CSAs (Wood, 2011).

\section{Study Site 1: Downtown Austin}

The downtown Austin farmers' market is a weekend market operated by the Austin Sustainable Food Center (SFC). It is the largest certifiedgrowers market in the state of Texas. The downtown Austin market is part of the Special Supplemental Nutrition Program for Women, Infants and Children (WIC) Farmers' Market
Nutrition Program (FMNP) and also accepts Lone Star food stamps (SNAP). In addition to a vast selection of produce, vendors sell dairy products, meat products, and additional specialty items. There are also hot food items and drinks available, and there is an outdoor seating area with a stage for musical acts and other performances. The market also sells nonfood items such as organic soaps, clothing, and crafts.

For the downtown Austin market, we compared prices to the closest H-E-B grocery store (2.3 miles or $3.7 \mathrm{~km}$ away) and nearby natural grocery store, ${ }^{2}$ Whole Foods Market (0.7 miles or $1.1 \mathrm{~km}$ away). H-E-B is an award-winning San Antonio-based supermarket chain that is the largest privately owned company in Texas, the largest private employer in Texas, and one of the largest supermarket chains in the U.S. (Pack, 2012; San Antonio Business Journal, 2010). H-E-B boasts a strong commitment to sourcing foods from producers within Texas, but the number of Texas brands and offerings varies according to seasonality and store location (H-E-B, n.d.). Austin-based Whole Foods Market is currently the world's largest natural and organic food retailer (Whole Foods Market, 2012). Whole Foods lists more than 2,400 natural and organic products in its Whole Foods, 365 Everyday Value, and Whole Catch brands (Whole Foods Market, 2012). Like H-E-B, Whole Foods has made a "permanent commit[ment] to buying from local producers," but the number of local offerings varies seasonally and by store location (Whole Foods Market, 2012).

\section{Study Site 2: Cedar Park}

The Cedar Park farmers' market is located in Cedar Park, Texas, a suburban community of 48,937 residents that shares a municipal boundary with Austin (U.S. Census Bureau, n.d.). The market is a member of the Farmers' Market Coalition, a nonprofit corporation, and is managed by F2M Texas, another nonprofit corporation (Central Texas Media, 2010). The Cedar Park farmers' market

\footnotetext{
2 "Natural grocer" is a self-identifying term used loosely by each of the stores chosen for this study. The term is also often used by upscale grocers to differentiate themselves from conventional supermarkets.
} 
opened in 2010 and is open year-round every Saturday morning. The market accepts Lone Star (SNAP) food stamps. There are approximately 50 vendors who participate at the Cedar Park farmers' market, and the diversity of food offerings closely resembles that of the downtown Austin market. The Cedar Park market does not have well defined rules about product origin, but similar to the downtown Austin market, the vast majority of products are sourced within a 150 -mile $(241-\mathrm{km})$ radius of the market (Cedar Park Farmers' Market 2012).

For the Cedar Park farmers' market, we compared prices to the nearest H-E-B (1.2 miles or 1.9 $\mathrm{km}$ away) and nearby natural grocery store (4.5 miles or $7.2 \mathrm{~km}$ away), in this case called Natural Grocers, a Colorado-based natural food retailer with over 50 locations nationwide. Natural Grocers sells a diverse selection of produce, meats, dairy products, bakery items, and other products. Natural Grocers sells "only natural and organic groceries and dietary supplements that meet our strict quality guidelines" (Natural Grocers, n.d.).

\section{Study Site 3: Georgetown}

The Georgetown farmers' market is located in Georgetown, Texas, a town of 47,400 residents approximately 25 miles ( $40 \mathrm{~km}$ ) north of Austin on Interstate I-35. This market is open on Thursday afternoons. The market is now open year-round, but at the time this research was conducted the market was open seasonally from the first Thursday in April until the week before Thanksgiving (Georgetown Farmers Market Association, n.d.). It was founded as a part of the Go Texan program under the Texas Department of Agriculture that encourages Texans to purchase local products. The Georgetown farmers' market is by far the smallest of the three study sites, hosting anywhere from 8 to 15 vendors, although there can be as many as 20 to 25 vendors. There is a large selection of local produce available, but the Georgetown market does not have the same level of diversity of meat and dairy items as the other study sites. The Georgetown farmers' market requires its vendors to sell items that are produced within Williamson County or one of 11 nearby counties. This market also accepts Lone Star (SNAP) food stamps.

For the Georgetown farmers' market, we compared prices with the nearby H-E-B (3.8 miles or $6.1 \mathrm{~km}$ away) and Sprouts Farmers' Market (8.1 miles or $13 \mathrm{~km}$ away), an Arizona-based natural food retailer with over 100 locations in the southwestern United States. It is important to mention that despite its name, Sprout's "Farmers' Market" openly states that it is not a traditional farmers' market, and while it offers a large selection of natural and organic food items and other products, it also carries a large number of "great-tasting mainstream foods" (Sprouts, n.d.).

\section{Methodology}

This research consisted of three interrelated methodological components, including price comparisons, surveys, and participant observation. As such, this was a QUAN (+qual) study - one that considers qualitative features to enhance the conduct and understanding of an otherwise purely quantitative study (Creswell \& Piano Clark, 2011). The result was a PCS intended to mimic the experience of the local food shopper while accounting for the complexity of the contemporary food retail landscape.

\section{Survey Methods}

The research for this study was conducted as part of a larger research project that included semistructured, open-ended surveys. The survey included 10 questions, but only two were written specifically with the PCS in mind. Approximately 400 surveys were completed and returned (Downtown Austin, $\mathrm{n}=146$; Cedar Park, $\mathrm{n}=180$; Georgetown, $\mathrm{n}=70$ ). We employed purposive convenience sampling based upon our ability to attract respondents within the space of the farmers' market. Put simply, all respondents who were shopping at that farmers' market on the day of the survey were invited to participate. Worth noting is that little demographic data (other than respondent zip code) was gathered in this study. Market operators welcomed our survey, but some requested that we conduct our research with minimal interference to normal market activity and with the greatest respect for patron privacy. As a result, we chose not to ask any demographic information (e.g. age, income, ethnicity, employment status) that might make participants feel uncomfortable or infringe on their privacy. 
To recruit participants, a table was set up at each farmers' market with a sign indicating that a survey was being conducted. Additionally, members of the research team walked through the market and asked patrons if they would like to participate in a survey of the farmers' market. If patrons chose to take the survey, they had the option of either filling out the survey themselves or being read the questions while a member of the research team recorded their responses. The survey was one page double-sided and consisted of 10 questions. Respondents were given the option of filling out the survey in either English or Spanish. The survey was open-ended and qualitative. Respondents were encouraged to "write as much or as little as they liked." All written and verbal results were fully transcribed and coded into suitable categories. The two questions in the survey written in order to complement the PCS were as follows:

(1) In your opinion, are most items more or less expensive at the farmers' market than at your local grocery store?

(2) What is the most important quality or qualities you look for in the items you purchase (examples: organic, local, GMOfree, taste, appearance, selection, etc.)? Would you be willing to pay more for these qualities?

\section{Price Comparison Study (PCS) Methods}

All prices were recorded in March and April 2012 in two separate rounds for each location to ensure accuracy, account for price fluctuations, and account for changes in seasonal availability. We recorded prices for 20 to 30 items at each farmers' market and then compared them to like items at a nearby conventional grocery store and nearby natural grocery store. To gain reliable comparisons within the market itself, we recorded prices from different vendors, and selected items in a way that replicated the known and observed behavior of patrons at the market (i.e., we chose a diverse basket of items based upon the growing practices, product origins, and appearance of food items as described in the literature, observed in the field, and articulated in survey responses). In addition, members of the research team interviewed farmers and vendors about their specific growing practices and recorded the farm location where each item was produced. The research team then recorded prices of the most qualitatively similar items available at the conventional grocery store and natural grocer within the local area. Information about certifications, labeling, growing practices, and food origins for items were recorded at all three locations. Prices for items at all locations were standardized by weight after the removal of water weight. These were listed as price per pound unless a different unit of measurement was deemed appropriate. ${ }^{3}$ As mentioned earlier, a second round of the PCS was conducted in April. In a few cases, the same item from the same vendor or retailer was recorded during the second round, and the price had changed. In the few instances when this occurred, we averaged the two prices.

Initially, we had planned to include only those items for which we could determine the precise origins, but this proved impossible for some items found at the conventional supermarket and natural grocers. For all food items gathered at the farmers' market, precise product origin was recorded and mapped (see Appendix D for this map). However, the supermarket and natural grocery stores do not always disclose the location of their suppliers. In these cases, we researched product origin by visiting their websites or contacting the producers directly. The results of this exercise varied. At times, companies were eager to provide the location of the producer farm. In other cases, companies were unwilling to disclose a more specific origin than a state or province.

In five specific cases, the store produce manager or company spokesperson was unable to provide any detailed information about the product origin. Consider the following example of our experience with a national organic milk company: As explained by a customer service representative, because they sourced milk from over 350 organic farms across the United States, and because different sources of milk were homogenized at a single processing plant, it was nearly impossible to track

\footnotetext{
${ }^{3}$ Examples of alternative measurements include eggs and milk, which are generally measured by the dozen and by the gallon or liter, respectively.
} 
down the origin of a single gallon of milk. That same milk was mass distributed from a separate location than the processing plant, further complicating the commodity chain and making it extremely difficult to determine the number of food miles traveled (customer service representative, personal communication, April 12, 2012).

In addition to considering product origin, we created a classification scheme that accounted for differences and similarities among food items. USDA and FDA certifications provide information for food consumers through the use of standardized labels, but these labels are not always used at farmers' markets. Markets have different rules about the use of terms like "organic" (which according to USDA regulations requires certification for any grower selling more than US $\$ 5,000$ per year of agricultural products), and most allow alternative labeling schemes in order to inform the consumer of "organic-like" practices (Guthman, 1998; Kremen, Greene, \& Hanson, 2004). But while labels such as "sustainably grown" or "beyond organic" are often appealing to consumers (Kremen et al., 2004), they do not conform strictly to standardized criteria. In order to account for this, we created a classification scheme that mimicked USDA and FDA standards while considering the different growing practices used by producers (see appendix B for this scheme).

Common supermarket labels and certifications were used for food prices recorded in that retail space (for example, USDA certified organic, naturally raised, free-range, vegetarian-fed, cagefree, conventional, hormone-free, etc.). For farmers who were USDA or FDA certified, we employ the same terms (e.g., "certified organic"). But as mentioned previously, some farmers choose not to pay the fees and complete the paperwork for USDA certification, and instead choose alternative labels. For farmers who abide by organic practices but do not have official USDA certification, we applied the term "organic practices"- $\mathrm{a}$ term that the reader will see frequently in tables 1-B and the three tables in appendix A. Also, many producers employ a mixture of organic and conventional practices. For instance, a large majority of the farmers do not use pesticides or herbicides and do not grow genetically modified produce (two key USDA organic standards), but still use chemical fertilizers for some of their crops. For these, the term "mixed practices" was used. A full description of the classification scheme can be found in Appendix B.

We recorded prices for 490 food items (see table 1-A for a summary of methods). For each round of data collection, we recorded prices for

\section{Table 1-A. Summary of Price Comparison Methods}

\begin{tabular}{ll}
\hline \multicolumn{1}{c}{ Method } & \multicolumn{1}{c}{ Description } \\
\hline Sampling & - Diverse basket of 20-30 items chosen at FM based upon growing practice, origin, and \\
& appearance. \\
- & Comparable items chosen at retail grocers that exhibited the greatest degree of similarity. \\
\hline Frequency & - Two rounds of data collection divided by one month (1st round: March 2012; 2nd round: April \\
& 2012). \\
\hline Data Recording (Price) & - Standardized by price per pound after removing excess water weight (in the case of produce). \\
& - Standardized by comparable volume (e.g. liter, gallon) for items such as milk and olive oil, or \\
& by piece for items such as eggs. \\
& - Sale prices not considered. \\
\hline - & Difference in prices between two rounds averaged. \\
- Growing practices recorded based upon interviews with supplier for FMs, or based upon \\
(Product Attribute) \\
- - Classification schemes for FM growing practices standardized for comparison with recognized \\
labels and certifications (Appendix B). \\
- Product origin recorded and mapped based upon interviews with supplier at FM, or in the case \\
of retail grocers, based upon interviews with retailers, labeling information, website \\
information, or communication with company spokesperson.
\end{tabular}


Table 1-B. Product Selection Chart (all prices in US\$)

$(\checkmark$ indicates items chosen for comparison)

\begin{tabular}{|c|c|c|}
\hline Farmers' Market & Conventional Supermarket & Natural Grocers \\
\hline $\begin{array}{c}\$ 6.45 / \mathrm{lb} . \checkmark \\
\text { Organic Practices } \\
\text { Manor, Texas (14 mi.) } \\
\text { Rounds } 1 \& 2\end{array}$ & $\begin{array}{l}\$ 2.24 / \mathrm{lb} \text {. } \\
\text { Conventional } \\
\text { Mexico (+200 mi.) } \\
\text { Round } 1 \text { only }\end{array}$ & $\begin{array}{l}\$ 2.88 / \mathrm{lb} . \\
\text { Conventional } \\
\text { Mexico }(+200 \mathrm{mi} .) \\
\text { Rounds } 1 \& 2\end{array}$ \\
\hline $\begin{array}{c}\$ 5.50 / \mathrm{lb} . \\
\text { Mixed Practices } \\
\text { La Grange, Texas (62 mi.) } \\
\text { Rounds } 1 \& 2\end{array}$ & $\begin{array}{c}\$ 3.98 / \mathrm{lb} . \checkmark \\
\text { Certified Organic } \\
\text { Salinas, California }(1,680 \mathrm{mi} .) \\
\text { Rounds } 1 \& 2\end{array}$ & $\begin{array}{c}\$ 5.16 / 1 \mathrm{~b} . \checkmark \\
\text { Certified Organic } \\
\text { Austin, Texas }(<5 \mathrm{mi} .) \\
\text { Rounds } 1 \& 2\end{array}$ \\
\hline $\begin{array}{c}\$ 5.50 / \mathrm{lb} . \\
\text { Mixed Practices } \\
\text { Bastrop, Texas (30 mi.) } \\
\text { Round } 1 \text { only }\end{array}$ & $\begin{array}{c}\$ 2.45 / \mathrm{lb} \text {. } \\
\text { Conventional } \\
\text { California }(+1,100 \mathrm{mi} .) \\
\text { Round } 2 \text { only }\end{array}$ & \\
\hline
\end{tabular}

Note: 1 mile $=1.6 \mathrm{~km}$

similar products at the farmers' market and compared them with the most qualitatively similar products at conventional and natural grocers based upon product origin (items that were produced closest to the retail venue) and growing practices (items that exhibited the most comparable production methods and/or certifications). Of the items that remained, only the most qualitatively similar items were then chosen for comparison. For instance, if we recorded prices of a pound of locally produced green onions, grown with organic practices, and sold at the farmers' market, we sought out green onions with the same or most similar attributes at the conventional and natural grocery stores. Eight bunches of green onions were recorded over three different venues, but only the "most similar" were considered for comparison (see table 1-B).

This method is intended to mimic the process that a selective consumer may use when presented with different options. In every instance we asked ourselves: if a consumer were looking for the highest standards and quality in their food item, which would he or she choose, and what would be the most comparable item at all three venues? ${ }^{4}$ Ultimately, 156 out of the original 490 food items were deemed suitable for comparison. This

\footnotetext{
${ }^{4}$ As stated previously, the items were selected based upon consumer preferences described in the literature, observed in the field, and articulated in survey responses.
}

includes 18 items from each retail space ( 54 total) in the downtown Austin market area, 18 items from each retail space (54 total) for the Cedar Park market area, and 16 items from each retail space (48 total) for the Georgetown area.

\section{Field Observation Methods}

Lastly, it is important to mention that members of the research team also engaged in various forms of field observation both as participant observers and onlookers (as described in Patton, 2002). Researchers walked through the farmers' market observing conversations between patrons and vendors and making field notes on the buying habits of farmers' market patrons. Also, researchers purchased items, spoke with vendors and consumers about specific products and growing practices, and engaged in numerous informal conversations with farmers' market patrons. Additionally, two researchers later volunteered as vendors at a farmers' market (although not at the same time prices were being recorded or the survey was being conducted). Another member of the research team volunteered as an intern at one of the producer farms. Lastly, another member of the research team visited one of the producer farms and observed its growing practices. At some point during the course of this study, all the researchers purchased items, gathered information about the products, and engaged in conversations with retailers and vendors beyond the formal interview process. In accordance with traditional field observation practices, these activities were carried out in a way that yielded "the most meaningful data... given the characteristics of the participants, the nature of staff-participant interactions, the socio-political context of the program, and the information needs of intended evaluation users" (Patton, 2002, p. 267). 


\section{Results}

The following sections detail the results of our survey and PCS. Note: the information provided in the surveys (particularly table 2-B) may prove useful for future researchers who wish to consider other food attributes beyond product origin, price, and growing practices.

\section{Survey Questions}

Two questions from the survey were relevant to this paper, and because the surveys were openended, many participants provided lengthy responses that added qualitative depth to the PCS. As mentioned previously, all responses were transcribed and coded into categories. The first question asked respondents if they thought the items at the farmers' market were more or less expensive than at their local grocery store (see table 2-A). Just over half of respondents at each location stated that items were more expensive at the farmers' market, but perhaps most interestingly, many respondents felt the need to justify the premium cost. For instance, 61 of the 84 respondents in the Cedar Park survey who answered "more expensive" justified their response with comments such as:

- "[It is] more expensive, but worth it in many cases. I'm here [because] of the variety, atmosphere and desire to support local food."

- "I don't care. It's [supporting] organic, local, individuals."

- "It is just a little more expensive for some items: eggs, meat. But freshness and quality offset the cost. We love the variety in produce."

Similar results were found in the Austin and Georgetown surveys, where respondents qualified their answers about price with comments such as:

- "It depends, but locally grown is an investment in the community! It's a civic duty!"

- "[It is] more but I am
Table 2-A. Responses to the survey question, In your opinion, are items more or less expensive at the farmers' market than at your local grocery store?

\begin{tabular}{lllll}
\hline \multicolumn{1}{c}{$\begin{array}{c}\text { Austin } \\
\mathrm{n}=121\end{array}$} & \multicolumn{2}{c}{$\begin{array}{c}\text { Cedar Park } \\
\mathrm{n}=162\end{array}$} & \multicolumn{1}{c}{$\begin{array}{c}\text { Georgetown } \\
\mathrm{n}=61\end{array}$} \\
\hline More $=66(55 \%)$ & More $=84(52 \%)$ & More & $=35(57 \%)$ \\
\hline Less $=14(12 \%)$ & Less $=18(11 \%)$ & Less & $=9(15 \%)$ \\
\hline Same $=23(19 \%)$ & Same $=21(13 \%)$ & Same $=4(7 \%)$ \\
\hline Depends $=15(12 \%)$ & Depends $=30(17 \%)$ & Depends $=9(15 \%)$ \\
\hline Unsure $=3(2 \%)$ & Unsure $=9(5 \%)$ & Unsure $=4(7 \%)$ \\
\hline
\end{tabular}


Table 2-B. Responses to the survey question, What is the most important quality or qualities you look for in the items you purchase?

Austin $(n=146)$

\begin{tabular}{llllllll}
\hline Local & $=$ & 88 & $(65.2 \%)$ & Quality & $=$ & 7 & $(5.2 \%)$ \\
\hline Organic & $=$ & 71 & $(52.6 \%)$ & Uniqueness & $=$ & 4 & $(3.0 \%)$ \\
\hline Taste & $=$ & 38 & $(28.1 \%)$ & Sustainable & $=$ & 4 & $(3.0 \%)$ \\
\hline Fresh & $=$ & 24 & $(17.8 \%)$ & Seasonality & $=$ & 2 & $(1.5 \%)$ \\
\hline Appearance & $=$ & 17 & $(12.6 \%)$ & Health & $=$ & 2 & $(1.5 \%)$ \\
\hline GMO-free & $=$ & 13 & $(9.6 \%)$ & Price & $=$ & 1 & $(0.7 \%)$ \\
\hline Selection & $=$ & 11 & $(8.1 \%)$ & Humane/Ethical & $=$ & 1 & $(0.7 \%)$ \\
\hline
\end{tabular}

Cedar Park $(\mathrm{n}=180)$

\begin{tabular}{|c|c|c|c|c|c|c|c|}
\hline Local & $=$ & 117 & $(67.6 \%)$ & Quality & $=$ & 9 & $(5.2 \%)$ \\
\hline Organic & $=$ & 88 & (50.9\%) & Price & $=$ & 9 & $(5.2 \%)$ \\
\hline Taste & $=$ & 46 & $(26.6 \%)$ & Uniqueness & $=$ & 4 & $(2.3 \%)$ \\
\hline Fresh & $=$ & 45 & $(26.0 \%)$ & Seasonality & $=$ & 2 & $(1.2 \%)$ \\
\hline Appearance & $=$ & 25 & $(14.5 \%)$ & Health & $=$ & 2 & $(1.2 \%)$ \\
\hline GMO-free & $=$ & 23 & $(13.3 \%)$ & Sustainable & $=$ & 2 & $(1.2 \%)$ \\
\hline Selection & $=$ & 20 & $(11.6 \%)$ & Humane/Ethical & $=$ & 1 & $(0.5 \%)$ \\
\hline
\end{tabular}

Georgetown $(n=70)$

\begin{tabular}{lllllll}
\hline Local & $=$ & 44 & $(64.7 \%)$ & Quality & 2 & $(2.9 \%)$ \\
\hline Organic & $=$ & 35 & $(51.5 \%)$ & Uniqueness & 1 & $(1.5 \%)$ \\
\hline Fresh & $=$ & 25 & $(36.8 \%)$ & Humane/Ethical & 1 & $(1.5 \%)$ \\
\hline Taste & $=$ & 21 & $(30.9 \%)$ & Seasonality & 1 & $(1.5 \%)$ \\
\hline GMO-free & $=$ & 12 & $(17.6 \%)$ & Sustainable & 1 & $(1.5 \%)$ \\
\hline Appearance & $=$ & 10 & $(14.7 \%)$ & & & \\
\hline Selection & $=$ & 5 & $(7.4 \%)$ & & & \\
\hline
\end{tabular}

\section{Price Comparison Study}

The price comparison study found great variation in price, growing practices, and product origin among food items from different study sites. In broad terms the data reveals that the farmers' markets, at least in this case study, were often more expensive than their competition at supermarkets and natural grocers. Only 4 out of 18 products at the downtown Austin farmers' market and 2 of 18 items at the Cedar Park farmers' market were lowest among comparable items at nearby retail stores. The Georgetown farmers' market seemed to be more competitive in terms of cost, with lowest prices for 7 out of 16 products. When the results from all three market areas are combined, 21 of the 52 recorded items were cheapest at the conven- tional supermarket sites, 17 were cheapest at the natural grocers, and 13 were cheapest at the farmers' markets.

Despite attempts to find the most qualitatively similar items for comparison, there were often key differences among available items. Product origin is the most apparent of these differences. All 52 of the farmers' market items recorded in PCS were produced in Texas, and most within a 50-mile $(80-\mathrm{km})$ radius. Only 11 of the comparable items at the natural grocery stores and 9 of the comparable supermarket items were grown in state, despite the inclusion of product origin as a key criterion for choosing items for comparison (see appendix D).

In contrast to product origin, it proved easier to find items of similar growing practices for comparison. A similar number of organic items, for instance, were purchased at the supermarket (29), the natural grocer (30), and the farmers' market (29). Overall, more than half the items at each of the locations were certified organic or were produced using organic practices. Also, many of the items grown at the farmers' market were grown using "mixed practices." Appendix A presents this information (price, product origin, and growing practices) in a way that is intended to be accessible to consumers for easy comparison.

\section{Discussion}

This study confirmed that competing consumer motivations, product diversity and availability, and the overall complexity of the food retail landscape must be accounted for if a PCS is to be both accurate and useful. The presentation of clear and accessible data is important for producers and consumers, but additionally, the inclusion of survey responses also proved insightful.

For producers, the information provided by question 1 (see table 2-A) gives some idea of consumer perceptions about price comparisons 
between the farmers' market and local grocers. But more importantly, the written responses to this question were also useful. ${ }^{5}$ Combined with the responses to question 2 (table 2-B), producers are given insight into consumer perceptions about pricing, have access to a list of qualities that consumers considered most desirable, and can read comments about how consumers justified those prices. They are also provided with some idea about consumer loyalty and the degree to which consumers are willing to pay more for certain food attributes. The tables in appendix A also allow producers to see how market prices compare both in price (quantitatively) and in attribute (qualitatively) to similar products at competing retail venues. In the interactive, conversational space of the farmers' market, such information can be extremely valuable for engaging with consumers (Kirschenmann, 2003).

For consumers, the information in appendix A is intended to provide them with easily comparable data about pricing in their local market area. By providing not just price, but also growing practices and product origin, consumers are able to evaluate potential purchases according to their own values and motivations. Also, by comparing these items by venue, the consumer can factor in convenience. Further, mapping product origins increases the accessibility of that information to consumers. ${ }^{6}$ For those consumers who are concerned with sourcing their food locally, appendix D leaves little doubt as to which venue provides the largest offering of local products.

An example here may help demonstrate the utility of this presentation: Consider strawberries chosen for comparison in the Georgetown market area and how a consumer might use this information. The strawberries sold by a vendor at that farmers' market were grown using organic practices near Elgin, Texas (approximately 35 miles or $56 \mathrm{~km}$ away), and were sold for US $\$ 4.00 / \mathrm{lb}$.

\footnotetext{
${ }^{5}$ As mentioned previously, a full list of comments was distributed to the farmers' market organizers.

${ }^{6}$ The map in appendix $\mathrm{C}$ presents how each venue defines "local," and the map in appendix D provides a quick visual reference for consumers who wish to see how each venue sources a basket of food items with comparable attributes.
}

This price is less than that of USDA-certified organic strawberries grown over 1,400 miles (2,253 $\mathrm{km}$ ) away in Oxnard, California, which was priced at the nearby supermarket for US $\$ 4.59 / \mathrm{lb}$. Both of these products were, however, more than double the cost of the conventional items purchased at the nearby natural grocery store, which were grown in Mexico and sold for US $\$ 2.00 / \mathrm{lb}$. In this example, it is easy to see how a consumer might weigh the values of product origin (and food miles traveled), growing practices, convenience, and price in order to better inform his or her purchase. Based upon the survey results, most patrons from the Georgetown farmers' market place value premiums on local, organic, and fresh produce (see table 2-B). The local, organically grown strawberries from the farmers' market match that description, and with a lower price than organically grown strawberries available from the nearby natural grocer, this item seems an easy choice for a food shopper in the Georgetown area.

However, other items present more complicated scenarios. Consider the example of tomatoes available in the Cedar Park market area. Locally grown, mixed-practice tomatoes sold at the Cedar Park farmers' market for US\$3.00/lb. are more expensive than the certified organic, Mexican-grown tomatoes available for US $\$ 2.19 / \mathrm{lb}$. at the nearby natural grocer. Both of these items are considerably more expensive than the conventionally grown tomatoes of unknown origin available for US $\$ 0.94 / \mathrm{lb}$. at the nearby supermarket. This comparison brings a host of values into play, and invites several questions. For instance, is the consumer concerned with USDA organic certification, or would he or she prefer to ask the farmers' market vendor about the farm's growing practices? Second, is this consumer concerned about the origin of the food item, and if so, how local is local enough (i.e., is it necessary for their food to be grown within a 10 -mile or $16-\mathrm{km}$ radius, 50 -mile or $80-\mathrm{km}$ radius, within state boundaries)? Lastly, how does convenience factor in this consumer's decision (consider, for instance, the limited hours of operation for the farmers' market)? These questions engage such issues as transparency in the food chain, support of local producers, and varying issues of environmental sustainability. 
A PCS table that offers local, detailed information about items and their prices may improve decision-making capacity for consumers, but additional survey questions may also provide insight. For instance, this study noted that consumers are willing to pay more for local and organic products, but exactly how much more they are willing to pay was not the main focus of this research. Additionally, more research is needed on those benefits of direct markets not directly tied to food attributes. For some consumers, having access to farmers and their agricultural knowledge is important. Others may prioritize support of the local economy. And yet others may visit the market for social interaction and community building. How these benefits translate into a measurable "price premium" could be valuable for both consumers and producers.

\section{Recommendations for Future Price Comparison Studies}

This research revealed many challenges in conducting a reliable and accessible PCS, and addressing these challenges led to the creation of an improved model for future studies. First, the decision to conduct two rounds of data collection strengthened the reliability of our data, but it did not adequately address the question of seasonality, a factor that may affect prices and that could be investigated in a longitudinal study. Second, while issues of convenience are discussed throughout this paper, this was not directly examined in the surveys. Almost certainly, consumers base part of their choices on location, hours of operation, and other factors of convenience, and while the information provided in appendix A may assist consumers in some measures of convenience, survey questions may provide insight into how those issues affect consumer behavior. Lastly, future researchers may wish to seek out additional information about respondent demographics. Such information may reveal patterns according to age, income, education level, or other characteristics of farmers' market shoppers.

In short, while we feel that this study represents a marked improvement on previous

\section{Table 3: An Improved Model for Local Price Comparison Studies}

\begin{tabular}{|c|c|}
\hline Method & Description \\
\hline Sampling & $\begin{array}{l}\text { - Choose a diverse basket of 20-30 items from different farmer' market (FM) vendors based upon } \\
\text { growing practice, product origin, and apparent quality. } \\
\text { - Select comparable items chosen at retail grocers that exhibit the greatest degree of similarity } \\
\text { based upon the above criteria. }\end{array}$ \\
\hline Frequency & $\begin{array}{l}\text { - } \quad \text { Choose dates that reflect seasonal variation (which varies according to region and climate). } \\
\text { - } \quad \text { Conduct two rounds of data collection per season to ensure accuracy of information. }\end{array}$ \\
\hline $\begin{array}{l}\text { Data Recording } \\
\quad \text { (Price) }\end{array}$ & $\begin{array}{l}\text { - Standardize by price per pound after removing excess water weight from produce. } \\
\text { - Standardize by comparable volume (e.g. liter, gallon) for items such as milk and olive oil, or by } \\
\text { piece for items such as eggs. } \\
\text { - Use the average price between the two rounds of data collection per season. }\end{array}$ \\
\hline $\begin{array}{l}\text { Data Recording } \\
\text { (Product Attribute) }\end{array}$ & $\begin{array}{l}\text { - Record growing practices based on certifications or interviews with vendors (in the case of the } \\
\text { FM), or on product labels, certifications, and website information (in the case of retail stores). } \\
\text { - Record product origin for all items and map that information. This information should be based } \\
\text { upon interviews with vendors (in the case of the FM), or should be based upon labeling } \\
\text { information, website information, or communication with company spokespersons (in the case of } \\
\text { retail grocers). } \\
\text { - Standardize classification schemes for FM growing practices for comparison with recognized } \\
\text { labels and certifications (see appendix B in this study for example). }\end{array}$ \\
\hline $\begin{array}{l}\text { Data Display and } \\
\text { Distribution }\end{array}$ & $\begin{array}{l}\text { - Present the data in a clear and accessible tabular display that includes cross comparisons of } \\
\text { items by food item and venue. } \\
\text { - Include information for each food item (average price, growing practice, and product origin) for } \\
\text { quick comparison. } \\
\text { Distribute the final display tables in a way that reaches the greatest number of vendors and } \\
\text { producers (by disseminating through FM managers or through direct contact) and potential } \\
\text { consumers (through local, mainstream media sources as well as alternative media sites such as } \\
\text { food blogs and social media). }\end{array}$ \\
\hline
\end{tabular}


price comparison studies, it can still be polished, and we have detailed these potential improvements in table 3. Further, while the methods are replicable, our findings are site-specific and suggest that studies in other regions may reveal certain differences. We offer the below recommendations for future studies and also include a new model for price comparison studies.

(1) Seasonality: Two rounds of data collection did not allow enough time to account for changes in seasonality, and we recommend that future studies include two rounds per growing season (depending on location and climate).

(2) Product Origin: Our inability to track the origin of several products reveals much about the lack of transparency in the food system, and it also may make comparisons difficult for some consumers who strongly value this attribute. It may also cast farmers' markets in a favorable light, since this information is usually readily available by speaking with the vendor. Future studies may wish to weigh the benefits and challenges of including only those products that reveal their source.

(3) Convenience: This was something that we did not explore in depth in our study, and which almost certainly influences consumers' choice of shopping venues. Future studies may wish to consider pursuing this issue.

(4) Food Attributes: Reflecting information within the literature about consumer preferences and attitudes, this study placed a high premium on growing practices and product origin. However, this may change in the future, and consumer preferences and attitudes also may be region-specific. Future studies may wish to consider additional attributes of the food items they choose for comparison (e.g. genetic modification, worker and animal welfare, etc.).

(5) Distribution of Information: We strongly recommend that future studies distribute this information to consumers and producers. We have chosen to share all our survey and PCS data with producers and organizers at the farmers' markets, as well as with the retail outlets where we conducted our comparisons. Once research has completed the peer-review process, we will be sharing a summary of the results with local media outlets in order to disseminate this information and encourage further scrutiny and improvement of this model.

\section{Conclusion}

This research builds upon the work of previous PCSs in order to create a new model that considers consumer preferences and the diversity of choices in the contemporary food landscape. The result is an improved, reproducible set of methods for PCSs that provides practical and accessible information to consumers and producers about food origin, growing practices, and of course, price. We argue that the utility and practicality of such a study is strengthened by presenting the results in a way that allows consumers to draw their own conclusions about the foods they value and the prices they are willing to pay. This information also provides small-scale producers with data that informs their business model and allows them to better connect to their customer base. Lastly, the results also suggest that methods for PCSs still have room for improvement. Issues such as seasonality and convenience need further attention, and information about other food qualities (such as data on worker and animal welfare, genetic modification, and other attributes) could be included to create a more comprehensive study. Ultimately, the most important result of this study is a more thorough model for price comparison studies that provides accessible and practical information for farmers' market producers and consumers. We encourage researchers to review this model, improve upon it, and conduct further studies.

\section{Acknowledgements}

The authors would like to express their sincere thanks to the farmers, vendors, patrons, and market administrators who facilitated this research. We would also like to offer a special thanks to Kimberly Nesmith, Carla Jenkins, Karen Banks, 
and Suzanne Santos, as well as the Austin Sustainable Food Center. Lastly, we wish to thank the editors and reviewers of the Journal of Agriculture, Food Systems, and Community Development whose helpful and constructive comments greatly improved this paper.

\section{References}

Adams, D. C., \& Adams, A. E. (2011). De-placing local at the farmers' market: Consumer conceptions of local foods. Journal of Rural Social Sciences, 26(2), 74-100.

Adams, D. C., \& Salois, M. J. (2010). Local versus organic: A turn in consumer preferences and willingness-to-pay. Renewable Agriculture and Food Systems, 25(4), 331-341. http://dx.doi.org/10.1017/S1742170510000219

Barrientos, S., \& Dolan, C. (2007). Ethical sourcing in the global food system. London: Earthscan Publications.

Bendrick, L. (2008). Eat where you live: How to find and enjoy fantastic local and sustainable food no matter where you live. Seattle: Skipstone.

Boucher, D. H. (Ed.). (1999). The paradox of plenty. Oakland, California: Food First Publications.

Burnett, P., Kuethe, T. H., \& Price, C. (2011). Consumer preference for locally grown produce: An analysis of willingness-to-pay and geographic scale. Journal of Agriculture, Food Systems, and Community Development, 2(1),: 269--278. http://dx.doi.org/10.5304/jafscd.2011.021.013

Carpio, C. E., \& Isengildina-Massa, O. (2009). Consumer willingness to pay for locally grown products: The case of South Carolina. Agribusiness, 25(3), 412-426.

http://dx.doi.org/10.1002/agr.20210

Central Tex Media. (2010, February 22). Cedar Park to get farmers market. Retrieved from http://cedarparktex. $\mathrm{com} / 2010 /$ cedar-park-to-get-farmers-market/

Claro, J. (2011). Vermont farmer's markets and grocery stores: A price comparison. Richmond, Vermont: Northeast Organic Farming Association of Vermont. Retrieved February 20, 2012, from http://nofavt.org/pricestudy

Creswell, J. W., \& Piano Clark, V. L. (2011). Designing and conducting mixed methods research. Thousand Oaks, California: Sage Publications.

DeLind, L. B. (2011). Are local food and the local food movement taking us where we want to go? Or are we hitching our wagons to the wrong stars? Agriculture and Human Values, 29(2), 273-283. http://dx.doi.org/10.1007/s10460-010-9263-0

Detre, J. D., Mark, T. B., \& Clark, B. M. (2010). Understanding why college-educated Millenials shop at farmers markets: An analysis of students at Louisiana State University. Journal of Food Distribution Research, 41(3), 14-24.

Farmer, J., Chancellor, C., Gooding, A., Shubowitz, D., \& Bryant, A. (2011). A tale of four farmers markets: Recreation and leisure as a catalyst for sustainability. Journal of Park and Recreation Administration, 29(3), 11-23.

Feagan, R. B., \& Morris, D. (2009). Consumer quest for embeddedness: A cause study of the Brantford Farmers' Market. International Journal of Consumer Studies, 33(3), 235-243. http://dx.doi.org/10.1111/ j.1470-6431.2009.00745.x

Fisher, D. (2012, April 18). America's fastest growing cities [Web log post]. Forbes. Retrieved from http://www.forbes.com/sites/danielfisher/2012/ 04/18/americas-fastest-growing-cities/

Florida, R. (2012, March 19). The U.S. cities with the fastest growing job markets [Web log post]. The Atlantic Cities. Retrieved from http://www.theatlanticcities.com/jobs-andeconomy/2012/03/us-cities-fastest-growing-jobmarkets/1504/\#

Galt, R. E. (2011). Counting and mapping community supported agriculture (CSA) in the United States and California: Contributions from critical cartography/GIS. ACME: An International E-Journal for Critical Geographies, 10(2), 131 -162.

Georgetown Farmers Market Association. (n.d.). Welcome to GFMA. Retrieved from http://www.gtfma.com/Welcome.html

Gunderson, M. A., \& Earl, A. N. (2010). Examining specialty crop price relationships between farmers markets and grocery stores. Journal of Food Distribution Research, 41(1), 51-57.

Guthman, J. (1998). Regulating meaning, appropriating nature: The codification of California organic agriculture. Antipode, 30(2), 135-154. http://dx.doi.org/10.1111/1467-8330.00071

H-E-B. (n.d.). Community involvement. Retrieved from http://www.heb.com/page/about-us/community/ community-involvement 
Hinrichs, C. C. (2000). Embeddedness and local food systems: Notes on two types of direct agricultural market. Journal of Rural Studies, 16(3), 295-303. http://dx.doi.org/10.1016/S0743-0167(99)00063-7

Hinrichs, C. C. (2003). The practice and politics of food system localization. Journal of Rural Studies, 19(1), 33-45. http://dx.doi.org/10.1016/S0743-0167 (02)00040-2

Hunt, A. R. (2007). Consumer interactions and influences on farmers' market vendors. Renewable Agriculture and Food Systems, 22(1), 54-66. http://dx.doi.org/10.1017/S1742170507001597

Kingsolver, B., Hopp, S. L., \& Kingsolver, C. (2007). Animal, vegetable, miracle: A year of food life. New York: Harper Collins.

Kirschenmann, F. (2003). The current state of agriculture: Does it have a future? In N. Wirzba (Ed.), The Essential Agrarian Reader: The Future of Culture, Community, and the Land (pp. 101-120). Lexington, Kentucky: University of Kentucky Press.

Kremen, A., Greene, C., \& Hanson, J. (2004). Organic produce, price premiums, and eco-labeling in U.S. farmers' markets (Report VGS-301-01). USDA Economic Research Service. Retrieved from http://www.ers.usda.gov/media/269468/ vgs30101 1.pdf

Lavin, C. (2009). The year of eating politically. Theory \& Event, 12(2). http://dx.doi.org/10.1353/tae.0.0074

Long, J. (2011). Entering the new conversational marketplace: Narratives of sustainability and the success of farm direct markets. Food, Culture and Society, 14(1), 49-69. http://dx.doi.org/10.2752/ 175174411X12810842291182

Lyon, P., Collie, V., Kvarnbrink, E.-B., \& Colquhoun, A. (2009). Shopping at the farmers' market: Consumers and their perspectives. Journal of Foodservice, 20(1), 21-30. http://dx.doi.org/ 10.1111/j.1748-0159.2008.00119.x

Lyson, T. A., Gillespie, G. W., \& Hilchey, D. (1995). Farmers' markets and the local community: Bridging the formal and informal economy. American Journal of Alternative Agriculture, 10(3), 108-113. http://dx.doi.org/10.1017/S0889189300006251

McEntee, J. (2010). Contemporary and traditional localism: A conceptualisation of rural local food. Local Environment, 15(9-10), 785-803. http://dx.doi.org/10.1080/13549839.2010.509390
McGuirt, J. T., Jilcott, S. B., Liu, H., \& Ammerman, A. S. (2011). Produce price savings for consumers at farmers' markets compared to supermarkets in North Carolina. Journal of Hunger and Environmental Nutrition, 6(1), 86-98. http://dx.doi.org/10.1080/19320248.2010.551031

McKibben, B. (2007). Deep economy: The wealth of communities and the durable future. New York: Henry Holt and Company.

Moser, R., Raffaelli, R., \& Thilmany-McFadden, D. (2011). Consumer preferences for fruit and vegetables with credence-based attributes: A review. International Food and Agribusiness Management Review, 14(2), 121-142.

Natural Grocers. (n.d.). About natural grocers. Retrieved from http://www.naturalgrocers.com/store-info/ about-natural-grocers

Nestle, M. (2002). Food politics: How the food industry influences nutrition and health. Berkeley, California: University of California Press.

Onianwa, O., Mojica, M. N., \& Wheelock, G. (2006). Consumer characteristics and views regarding farmers markets: An examination of on-site survey data of Alabama consumers. Journal of Food Distribution Research, 37(1), 119-125.

Pack, W. (2012, July 10). CNBC says Texas top state for biz. MySA. Retrieved from http://www.mysanantonio.com/business/article/ CNBC-says-Texas-top-state-for-biz-3697357.php

Patel, R. (2008). Stuffed and starved: The hidden battle for the world food system. Brooklyn, New York: Melville House Publishing.

Patton, M.Q. (2002). Qualitative research and evaluation methods. Thousand Oaks, California: Sage Publications.

Pirog, R., \& McCann, N. (2009). Is local food more expensive? A consumer price perspective on local and non-local foods purchased in Iowa. Ames, Iowa: Leopold Center for Sustainable Agriculture. Retrieved from http://www.leopold.iastate.edu/pubs-andpapers/2009-12-local-food-more-expensive

Pollan, M. (2006). The omnivore's dilemma: A natural history of four meals. New York: Penguin Press.

Pollan, M. (2008). In defense of food: An eater's manifesto. New York: Penguin Press.

Pollan, M. (2009). Food rules: An eater's manual. New York: Penguin Press. 
San Antonio Business Journal. (2010, October 6). $\mathrm{H}-\mathrm{E}-\mathrm{B}$ is the country's top supermarket retailer. Retrieved from http://www.bizjournals.com/ sanantonio/stories/2010/10/04/daily22.html

Schlosser, E. (2001). Fast food nation: The dark side of the all-American meal. New York: Houghton Mifflin.

Shiva, V. (2000). Stolen harvest: The hijacking of the global food supply. Cambridge, Massachusetts: South End Press.

Sommer, R., Wing, M., \& Aitkens, S. (1980). Price savings to consumers at farmers' markets. Journal of Consumer Affairs, 14(2), 452-462. http://dx.doi.org/10.1111/j.1745-6606.1980. tb00681.x

Sprouts. (n.d.). About Sprouts: It's Healthy Living for Less. Retrieved from http://sprouts.com/about

Svenfelt, A., \& Carlsson-Kanyama, A. (2010). Farmers' markets - Linking food consumption and the ecology of food production? Local Environment, 15(5), 453-465. http://dx.doi.org/10.1080/13549831003735411

Tiemann, T. (2008). Grower-only farmers' markets: Public spaces and third places. The Journal of Popular Culture, 41(3), 467-487. http://dx.doi.org/10.1111/j.1540-5931.2008. 00531.x

Toler, S., Briggeman, B., Lusk, J., \& Adams, D. (2009). Fairness, farmers markets, and local production. American Journal of Agricultural Economics, 91(5), 1272-1278. http://dx.doi.org/10.1111/j.1467$\underline{8276.2009 .01296 . x}$
U.S. Census Bureau. (n.d.). American FactFinder: Demographics of major Texas cities. Retrieved February 10, 2012, from http://factfinder2.census.gov/

United States Department of Agriculture [USDA]. (2012). Farmers markets and local food marketing. Retrieved 2 February 2, 2012, from http://www.ams.usda.gov/AMSv1.0/ farmersmarkets

Whole Foods Market. (2012). Company info. Retrieved August 3, 2012, from http://www.wholefoodsmarket.com/company-info

Winter, M. (2003). Embeddedness, the new food economy and defensive localism. Journal of Rural Studies, 19(1), 23-32. http://dx.doi.org/10.1016/S0743-0167(02)00053-0

Wolf, M. M., Spittler, A., \& Ahern, J. (2005). A profile of farmers' market consumers and the perceived advantages of produce sold at farmers' markets. Journal of Food Distribution Research, 36(1), 192-201.

Wood, V. B. (2011, February 18). Local is as local does: Why area farmers want you to beware of faux local. Austin Chronicle. Retrieved from http://www.austinchronicle.com/food/2011-02$\underline{18 / \text { local-is-as-local-does/ }}$

Zepeda, L. (2009). Which little piggy goes to market? Characteristics of US farmers' market shoppers. International Journal of Consumer Studies, 33(3), 250257. http://dx.doi.org/10.1111/j.1470-6431.2009. 00771.x

Zepeda, L., \& Li, J. (2006). Who buys local food? Journal of Food Distribution Research, 37(3), 1-11. 


\section{Appendix A. Price Comparison Tables for Three Study Sites}

\section{Austin PCS}

* denotes the lowest price per comparison.

\begin{tabular}{|c|c|c|c|}
\hline Item & FM & Supermarket & Natural Grocer \\
\hline \multirow{3}{*}{ Artichoke } & $2.42 / \mathrm{lb} . *$ & 3.48/lb. & $5.32 / \mathrm{lb}$. \\
\hline & Conventional & Conventional & Certified Organic \\
\hline & Taylor, TX & Castroville, CA & California, USA \\
\hline \multirow{3}{*}{ Bacon } & $6.50 / \mathrm{lb} .^{*}$ & 6.99/lb. & 9.58/lb. \\
\hline & Pastured & Conventional & Naturally Raised \\
\hline & Rosanky, TX & Canada & Hamilton, TX \\
\hline \multirow{3}{*}{ Beets } & $2.00 / \mathrm{lb}$ & 1.59/lb. & $0.75 / \mathrm{lb} . *$ \\
\hline & Organic Practices & Certified Organic & Certified Organic \\
\hline & Austin, TX & Nevada City, CA & La Monte, CA \\
\hline \multirow{3}{*}{ Broccoli } & $3.00 / \mathrm{lb}$. & $2.49 / \mathrm{lb}$ & $1.88 / \mathrm{lb} .^{*}$ \\
\hline & Certified Organic & Certified Organic & Certified Organic \\
\hline & Austin, TX & Santa Maria, CA & Kern County, CA \\
\hline \multirow{3}{*}{ Cabbage } & $2.00 / \mathrm{lb}$ & $0.44 / \mathrm{lb} .^{*}$ & $1.29 / \mathrm{lb}$ \\
\hline & Organic Practices & Conventional & Organic \\
\hline & Manor, TX & Hondo, TX & California, USA \\
\hline \multirow{3}{*}{ Carrots } & $1.79 / \mathrm{lb} .^{*}$ & 1.98/lb. & 3.32/lb. \\
\hline & Organic Practices & Certified Organic & Certified Organic \\
\hline & Lytle, TX & La Monte, CA & Santa Maria, CA \\
\hline \multirow{3}{*}{ Chevre } & 20.00/lb. & $15.36 / \mathrm{lb}^{*}$ & $21.00 / \mathrm{lb}$ \\
\hline & Conventional & Conventional & Conventional \\
\hline & Waller, TX & Wisconsin, USA & Dripping Springs, TX \\
\hline \multirow{3}{*}{ Eggs } & 5.00/dozen. & 4.10/dozen.* & 4.79/dozen. \\
\hline & $\begin{array}{c}\text { Free Roaming, Organic } \\
\text { Practices }\end{array}$ & $\begin{array}{c}\text { Cage Free, Certified Organic, } \\
\text { Vegetarian Fed }\end{array}$ & $\begin{array}{c}\text { Cage Free, Certified Organic, } \\
\text { Vegetarian Fed }\end{array}$ \\
\hline & Fredericksburg, TX & Chase, KS & La Farge, WI \\
\hline \multirow{3}{*}{ Green Onions } & $6.45 / \mathrm{lb}$ & 3.98/Ib.* & $5.16 / \mathrm{lb}$ \\
\hline & Organic Practices & Certified Organic & Certified Organic \\
\hline & Manor, TX & Salinas, CA & Austin, TX \\
\hline \multirow{3}{*}{ Lettuce } & $8.00 / \mathrm{lb}$. & $2.48 / \mathrm{lb} .^{*}$ & 3.93/lb. \\
\hline & Certified Organic & Certified Organic & Certified Organic \\
\hline & Austin, TX & California, USA & California, USA \\
\hline \multirow{3}{*}{ Olive Oil } & 14.20/liter* & 16.93/liter* & 20.69/liter* \\
\hline & Conventional & Conventional & Conventional \\
\hline & Texas, USA & Texas, USA & Texas, USA \\
\hline \multirow{3}{*}{ Parsley } & 10.53/Ib. & $1.96 / \mathrm{lb} .^{*}$ & $2.98 / \mathrm{lb}$ \\
\hline & Certified Organic & Certified Organic & Certified Organic \\
\hline & Austin, TX & No Data & California, USA \\
\hline \multirow{3}{*}{ Radish } & $2.82 / \mathrm{lb}$ & $1.98 / \mathrm{lb} .^{*}$ & $2.54 / \mathrm{lb}$. \\
\hline & Organic Practices & Conventional & Conventional \\
\hline & Mullin, TX & Muranaka, Mexico & No Data \\
\hline \multirow{3}{*}{ Sourdough Bread } & $4.50 / \mathrm{lb}$ & 2.66/lb. & $2.66 / \mathrm{lb}$ \\
\hline & Conventional & Conventional & Conventional \\
\hline & Austin, TX & USA & USA \\
\hline
\end{tabular}




\begin{tabular}{|c|c|c|c|}
\hline \multirow{3}{*}{ Spinach } & $5.00 / \mathrm{lb}$. & $1.71 / \mathrm{lb} . *$ & 3.54/Ib. \\
\hline & Certified Organic & Certified Organic & Certified Organic \\
\hline & Austin, TX & Bakersfield, CA & San Juan Bautista, CA \\
\hline \multirow{3}{*}{ Strawberries } & 6.50/lb. & 3.98/Ib.* & $5.44 / \mathrm{lb}$ \\
\hline & Organic Practices & Certified Organic & Certified Organic \\
\hline & Lytle, TX & Oxnard, CA & Mexico \\
\hline \multirow{3}{*}{ Sweet Potatoes } & $2.38 / \mathrm{lb}$ & $.78 / \mathrm{lb} . *$ & 1.99/lb. \\
\hline & Organic Practices & Conventional & Conventional \\
\hline & Lytle, TX & No Data & California, USA \\
\hline \multirow{3}{*}{ Tomatoes } & $3.50 / \mathrm{lb}$. & $1.98 / \mathrm{lb}$. & $1.99 / \mathrm{lb}$. \\
\hline & Organic Practices & Conventional & Conventional \\
\hline & Kyle, TX & Guadeloupe, Mexico & Marfa, TX \\
\hline
\end{tabular}

$\mathrm{CA}=$ California; $\mathrm{KS}=$ Kansas; $\mathrm{TX}=$ Texas; $\mathrm{WI}=$ Wisconsin 
Cedar Park PCS

\begin{tabular}{|c|c|c|c|}
\hline Item & FM & Supermarket & Natural \\
\hline \multirow{3}{*}{ Broccoli } & $2.50 / \mathrm{lb}$ & $1.69 / \mathrm{lb}$. & $1.03 / \mathrm{Ib} .^{*}$ \\
\hline & Organic Practices & Certified Organic & Certified Organic \\
\hline & Austin, TX & Lamont, CA & Colorado, USA \\
\hline \multirow{3}{*}{ Cremini Mushrooms } & $5.50 / \mathrm{lb}$ & 3.98/Ib.* & 6.06/lb. \\
\hline & Conventional & Conventional & Certified Organic \\
\hline & Gonzales, TX & Madisonville, TX & USA \\
\hline \multirow{3}{*}{ Green Cabbage } & $2.00 / \mathrm{lb}$ & $1.47 / \mathrm{lb}$ & 1.09/lb.* \\
\hline & Organic Practices & Certified Organic & Certified Organic \\
\hline & Austin, TX & Lamont, CA & Austin, TX \\
\hline \multirow{3}{*}{ Carrots } & $3.77 / \mathrm{lb}$ & $1.10 / \mathrm{lb}$ & 1.09/lb.* \\
\hline & Certified Organic & Organic & Organic \\
\hline & Austin, TX & Lamont, CA & Lamont, CA \\
\hline \multirow{3}{*}{ Eggs } & 4.50/dozen & 4.10/dozen* & 5.89/dozen \\
\hline & $\begin{array}{l}\text { Organic practices, } \\
\text { Free-roaming }\end{array}$ & $\begin{array}{l}\text { Organic, } \\
\text { Cage-free }\end{array}$ & $\begin{array}{c}\text { Organic, } \\
\text { Free-roaming }\end{array}$ \\
\hline & Rogers, TX & Chase, KS & Austin, TX \\
\hline \multirow{3}{*}{ Green Onions } & $5.56 / \mathrm{lb}$. & 2.94/Ib. & $2.00 / \mathrm{Ib} . *$ \\
\hline & Organic Practices & Certified Organic & Certified Organic \\
\hline & Austin, TX & Lamont, CA & Austin, TX \\
\hline \multirow{3}{*}{ Granola } & 12.00/lb. & $3.22 / \mathrm{lb} . *$ & 17.98/lb. \\
\hline & Mixed practices & Conventional & Certified Organic \\
\hline & Cedar Park, TX & St. Louis, MO & Lafayette, CO \\
\hline \multirow{3}{*}{ Hummus } & $5.00 / \mathrm{lb} . *$ & $5.76 / \mathrm{lb}$ & $5.30 / \mathrm{lb}$ \\
\hline & Conventional & Conventional & Conventional \\
\hline & Leander, TX & San Antonio, TX & Austin, TX \\
\hline \multirow{3}{*}{ Kale } & 4.69/lb. & 3.96/lb. & 2.69/Ib.* \\
\hline & Organic Practices & Certified Organic & Certified Organic \\
\hline & Austin, TX & South Carolina, USA & Austin, TX \\
\hline \multirow{3}{*}{ Milk } & 7.00/gallon & 5.98/gallon & 5.75/gallon* \\
\hline & Naturally Produced & Certified Organic & Certified Organic \\
\hline & McGregor, TX & Bloomfield, $\mathrm{CO}$ & Hopkins County, TX \\
\hline \multirow{3}{*}{ Mozzarella } & 10.00/lb. & $5.29 / \mathrm{lb} . *$ & $5.78 / \mathrm{lb}$ \\
\hline & Naturally Produced & Conventional & Conventional \\
\hline & Kemp, TX & San Antonio, TX & Green Bay, WI \\
\hline \multirow{3}{*}{ Olive Oil } & 49.98/liter & 7.80/liter & 24.47/liter \\
\hline & Organic Practices & Conventional & Certified Organic \\
\hline & Dripping Springs, TX & Spain & Spain \\
\hline \multirow{3}{*}{ Red Leaf Lettuce } & $5.00 / \mathrm{lb}$ & $3.81 / \mathrm{lb}$. & $2.00 / \mathrm{Ib}{ }^{*}$ \\
\hline & Organic Practices & Certified Organic & Certified Organic \\
\hline & Burnet, TX & Lamont, CA & Central Southern CA \\
\hline \multirow{3}{*}{ Strawberries } & 7.69/lb. & $3.98 / \mathrm{lb}$ & $3.99 / \mathrm{lb}$. \\
\hline & Organic Practices & Certified Organic & Certified Organic \\
\hline & Burnet, TX & Santa Maria, CA & California \\
\hline \multirow{3}{*}{ Spinach } & $5.00 / \mathrm{lb}$ & $3.00 / \mathrm{lb}$. & 1.99/lb.* \\
\hline & Organic Practices & Certified Organic & Certified Organic \\
\hline & Austin, TX & Guanajuato, Mexico & Austin, TX \\
\hline
\end{tabular}


Journal of Agriculture, Food Systems, and Community Development ISSN: 2152-0801 online

www.AgDevjournal.com

\begin{tabular}{|c|c|c|c|}
\hline \multirow{3}{*}{ Sourdough bread } & $2.25 / \mathrm{Ib} . *$ & 3.98/lb. & 3.34/lb. \\
\hline & Mixed Practices & Conventional & Certified Organic \\
\hline & Austin, TX & San Antonio, TX & Boulder, CO \\
\hline \multirow{3}{*}{ Shrimp } & 13.00/lb. & $8.98 / \mathrm{lb} . *$ & 16.98/lb. \\
\hline & Wild Caught & Wild Caught & Farm Raised \\
\hline & Matagorda Bay, TX & Gulf of Mexico, USA & Dover, NH \\
\hline \multirow{3}{*}{ Tomatoes } & $3.00 / \mathrm{lb}$. & $0.94 / \mathrm{lb} . *$ & $2.19 / \mathrm{lb}$ \\
\hline & Mixed practices & Conventional & Certified Organic \\
\hline & Kingsbury, TX & USA/Mexico & Mexico \\
\hline
\end{tabular}

$\mathrm{CA}=$ California; $\mathrm{CO}=$ Colorado; $\mathrm{KS}=$ Kansas; $\mathrm{MO}=$ Missouri $\mathrm{NH}=$ New Hampshire; $\mathrm{TX}=$ Texas; $\mathrm{WI}=$ Wisconsin 


\section{Georgetown PCS}

\begin{tabular}{|c|c|c|c|}
\hline Item & FM & Supermarket & Natural Grocer \\
\hline \multirow{3}{*}{ Artichoke } & $1.54 / \mathrm{lb} . *$ & $4.29 / \mathrm{Ib}$. & $5.04 / \mathrm{lb}$. \\
\hline & Conventional & Conventional & Conventional \\
\hline & Taylor, TX & Mexico & USA \\
\hline \multirow{3}{*}{ Bacon } & $6.00 / \mathrm{lb}$. & 3.97/lb.* & 7.99/lb. \\
\hline & Naturally Raised & Conventional & Naturally Raised \\
\hline & Thorndale, TX & San Antonio, TX & Alameda, CA \\
\hline \multirow{3}{*}{ Beets } & $.91 / \mathrm{lb}$ * & 1.75/Ib. & $2.26 / \mathrm{Ib}$. \\
\hline & Organic Practices & Certified Organic & Certified Organic \\
\hline & Granger, TX & California & El Centro, CA \\
\hline \multirow{3}{*}{ Green Cabbage } & $.42 / \mathrm{lb} .^{*}$ & $.44 / \mathrm{Ib}$ & $.49 / \mathrm{lb}$. \\
\hline & Mixed Practices & Conventional & Conventional \\
\hline & Taylor, TX & Texas & California \\
\hline \multirow{3}{*}{ Carrots } & $2.60 / \mathrm{lb}$ & $2.46 / \mathrm{Ib}$. & $2.11 / \mathrm{lb} . *$ \\
\hline & Mixed Practices & Certified Organic & Conventional \\
\hline & Taylor, TX & California & Bakersfield, CA \\
\hline \multirow{3}{*}{ Eggs } & 4.00/Dozen* & 4.99/Dozen & 4.10/Dozen \\
\hline & Free Range, Organic Practices & Cage Free, Certified Organic & Cage Free, Naturally Raised \\
\hline & Georgetown, TX & La Farge, Wl & Gonzalez, TX \\
\hline \multirow{3}{*}{ Green Onions } & $4.88 / \mathrm{Ib}$ & $3.58 / \mathrm{lb}$ & $2.97 / \mathrm{lb} .^{*}$ \\
\hline & Conventional & Conventional & Certified Organic \\
\hline & Elgin, TX & Mexico & USA \\
\hline \multirow{3}{*}{ Honey } & $7.00 / \mathrm{lb}$ & 5.38/lb. & 5.99/lb. \\
\hline & Naturally Raised & Certified Organic & Conventional \\
\hline & Georgetown, TX & Brazil & Phoenix, AZ \\
\hline \multirow{3}{*}{ Kale } & $1.36 / \mathrm{lb} .{ }^{*}$ & 2.83/lb. & 3.62/lb. \\
\hline & Organic Practices & Certified Organic & Certified Organic \\
\hline & Granger, TX & La Monte, CA & El Centro, CA \\
\hline \multirow{3}{*}{ Romaine Lettuce } & $1.39 / \mathrm{lb} . *$ & $2.20 / \mathrm{lb}$ & $1.67 / \mathrm{lb}$ \\
\hline & Organic Practices & Certified Organic & Certified Organic \\
\hline & Granger, TX & Mexico & No Data \\
\hline \multirow{3}{*}{ Radishes } & $2.86 / \mathrm{lb}$ & $2.81 / \mathrm{lb}$. & 2.54/Ib.* \\
\hline & Mixed Practices & Certified Organic & Conventional \\
\hline & Taylor, TX & Bakersfield, CA & No Data \\
\hline \multirow{3}{*}{ Sourdough Bread } & 4.45/lb. & 3.98/lb. & 3.89/lb.* \\
\hline & Conventional & Conventional & Conventional \\
\hline & Austin, TX & San Antonio, TX & Scottsdale, AZ \\
\hline \multirow{3}{*}{ Spinach } & 4.88/lb. & $2.68 / \mathrm{lb}$. & 2.35/Ib.* \\
\hline & Mixed Practices & Certified Organic & Conventional \\
\hline & Elgin, TX & Bakersfield, CA & Mexico \\
\hline \multirow{3}{*}{ Strawberries } & 4.00/lb. & 4.59/lb. & 2.00/Ib.* \\
\hline & Organic Practices & USDA Organic & Conventional \\
\hline & Elgin, TX & Oxnard, CA & Mexico \\
\hline \multirow{3}{*}{ Swiss Chard } & 1.69/Ib.* & 2.83/lb. & 3.73/lb. \\
\hline & Organic Practices & Certified Organic & Conventional \\
\hline & Weir, TX & Bakersfield, CA & Ventura, CA \\
\hline \multirow[b]{2}{*}{ Zucchini } & $1.89 / \mathrm{lb}$ & $1.28 / \mathrm{lb}$ & $.99 / \mathrm{lb}{ }^{*}$ \\
\hline & $\begin{array}{c}\text { Mixed Practices } \\
\text { Briggs, TX }\end{array}$ & $\begin{array}{l}\text { Conventional } \\
\text { USA/Mexico }\end{array}$ & $\begin{array}{c}\text { Conventional } \\
\text { Mexico }\end{array}$ \\
\hline
\end{tabular}

$A Z=$ Arizona; $C A=$ California; $T X=$ Texas; $W I=$ Wisconsin 


\section{Appendix B. Growing Practices Classification}

\begin{tabular}{|c|c|}
\hline Cage-free & $\begin{array}{l}\text { Hens are uncaged inside barns or warehouses with unlimited access to food and } \\
\text { fresh water, but they generally do not have access to the outdoors (USDA, 2012). }\end{array}$ \\
\hline Certified organic & $\begin{array}{l}\text { A label given by the United States Department of Agriculture (USDA, 2012) to } \\
\text { identify products that have been produced in an ecologically and environmentally } \\
\text { sound manner. For certified organic produce, synthetic fertilizers, prohibited } \\
\text { pesticides, sewage sludge, irradiation, and genetic engineering are not permitted. } \\
\text { For organic livestock, no antibiotics or growth hormones are permitted, 100\% } \\
\text { organic feed must be given, and the livestock must have access to the outdoors. }\end{array}$ \\
\hline Conventional practices & $\begin{array}{l}\text { Do not follow the guidelines of organic practices; pesticides, fertilizers, and external } \\
\text { energy inputs may be used. This may include crops that have been genetically } \\
\text { modified. In terms of livestock, the animals may be confined to concentrated areas, } \\
\text { given certain antibiotics, as well as fed certain food. }\end{array}$ \\
\hline Free roaming & $\begin{array}{l}\text { Hens are uncaged inside barns or warehouses and have some degree of outside } \\
\text { access. There are no set requirements for the amount, duration, or quality of } \\
\text { access (USDA, 2012). }\end{array}$ \\
\hline Mixed practices & $\begin{array}{l}\text { This term is primarily used to discuss particular farmers' practices from the } \\
\text { farmers' market. After discussion with the farmers, we identified mixed practices to } \\
\text { indicate the attempt to be as organic as possible, but occasionally using fertilizers } \\
\text { or pesticides not supported by organic growing practices. }\end{array}$ \\
\hline Natural practices & $\begin{array}{l}\text { The product has been minimally processed and contains no preservatives or } \\
\text { artificial ingredients. There are no standards regulating farm practices (USDA, } \\
\text { 2012). }\end{array}$ \\
\hline Naturally raised & $\begin{array}{l}\text { The use of hormones, antibiotics, and animal byproducts is prohibited (USDA, } \\
\text { 2012). }\end{array}$ \\
\hline Organic practices & $\begin{array}{l}\text { Not certified by the USDA, but follow the exact or similar guidelines outlined for the } \\
\text { USDA certified organic label. This was only used to describe practices by the } \\
\text { farmers' market vendors based on their personal description of their growing } \\
\text { practices. }\end{array}$ \\
\hline Pastured & $\begin{array}{l}\text { There is no USDA label for pasture-raised animals, but the term refers to livestock } \\
\text { that has been raised primarily outdoors (USDA, 2012). }\end{array}$ \\
\hline Vegetarian fed & Hens are fed food that does not contain animal byproducts (USDA, 2012). \\
\hline
\end{tabular}


Appendix C. Map of Local Definitions by Venue Type

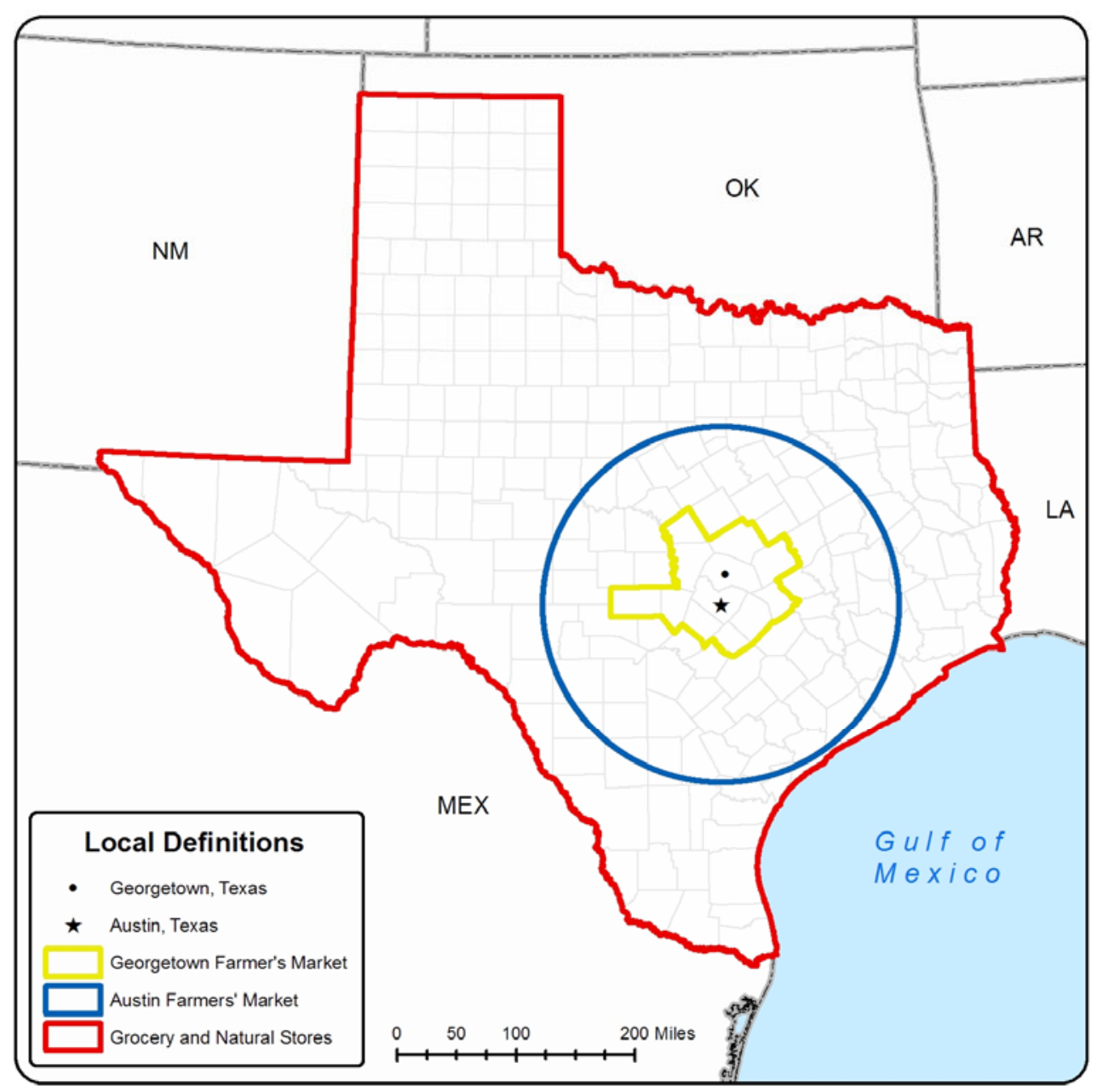


Appendix D. Maps of Item Product Origins by Venue

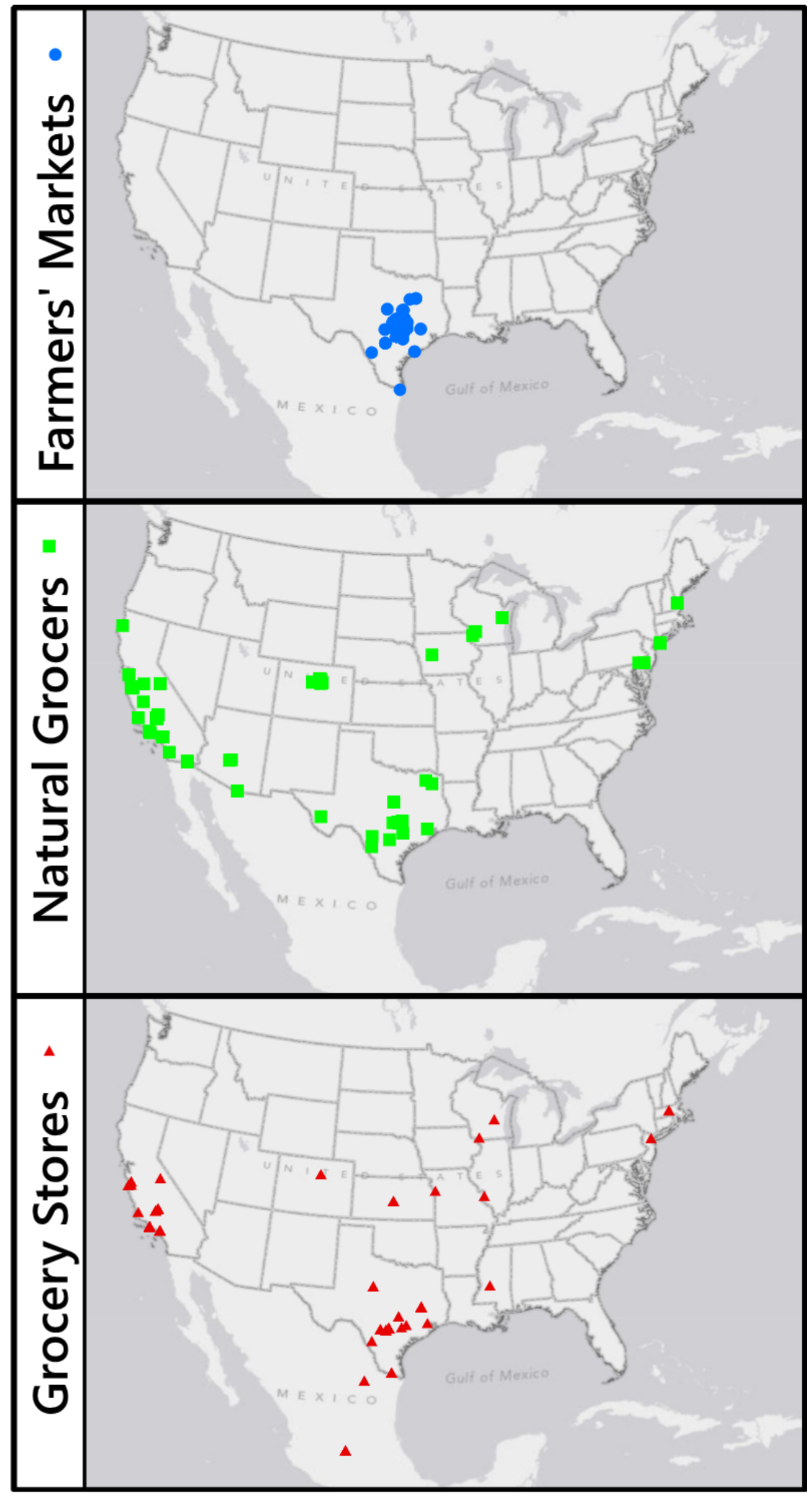

